\title{
Analisis Tingkat Kebisingan di Lingkungan Universitas PGRI Palembang
}

\author{
Atina $^{1 *}$, Jumingin ${ }^{2}$, Widya Rahmadani ${ }^{3}$, Indah Sukria ${ }^{4}$ \\ *e-mail: atina.salsabila@gmail.com \\ Program Studi Fisika, Fakultas Sains dan Teknologi \\ Universitas PGRI Palembang
}

\begin{abstract}
The purpose of this study was to determine the level of noise caused by vehicles on campus A at PGRI Palembang University. Noise measurements were carried out in 3 different places that were passed by the vehicles of employees and students, namely the parking lot of Building A, Building B and Building C. The study was conducted in October 2020 for 5 working days of data collection. The measurement result data is analyzed by calculating the respective Leq as a measured noise level, then the Leq is compared with the quality standards recommended by the government for noise in educational institutions. The results showed that the noise in the campus A environment of PGRI Palembang University was in the range of Leq 57.3012 - $73.9548 \mathrm{dBA}$ and did not meet the noise level quality standard for educational institutions, namely $55 \mathrm{dBA}$. This is because the location of the measurement is close to the traffic of vehicles.
\end{abstract}

Keywords: noise level, parking lot, Leq, Campus A PGRI Palembang University

\begin{abstract}
ABSTRAK
Tujuan penelitian ini adalah mengetahui tingkat kebisingan yang disebabkan kendaraaan di lingkungan kampus A Universitas PGRI Palembang. Pengukuran kebisingan dilakukan di 3 tempat yang berbeda yang dilalui kendaraan pegawai dan mahasiswa, yaitu lapangan parkir Gedung A, Gedung B dan Gedung C. penelitian dilakukan pada Oktober 2020 selama 5 hari kerja pengambilan data. Data hasil pengukuran dianalisis dengan menghitung Leq masing-masing sebagai tingkat kebisingan terukur, kemudian Leq dibandingkan dengan standar baku mutu yang direkomendasikan pemerintah untuk kebisingan di lingkungan Lembaga Pendidikan. Hasil penelitian menunjukkan kebisingan di lingkungan kampus A Universitas PGRI Palembang berada pada rentang Leq 57,3012 - 73,9548 dBA dan belum memenuhi baku mutu tingkat kebisingan untuk lembaga pendidikan yaitu 55 dBA. Hal ini dikarenakan dekatnya tempat pengukuran dengan jalan lalu lalang kendaraan.
\end{abstract}

Kata Kunci: tingkat kebisingan, parkiran, Leq, Kampus A Universitas PGRI Palembang 


\section{PENDAHULUAN}

Dalam bidang sains, terdapat
parameter yang menjadi acuan
pengukuran dalam penyusunan dokumen
lingkungan hidup. Lingkungan hidup
adalah suatu benda, daya dan kondisi
yang terdapat dalam suatu tempat atau
ruang tempat manusia dan makhluk hidup
berada dan dapat mempengaruhi
hidupnya (Bleszeinsky, G dkk, 2019). Parameter ini dapat dijadikan acuan dalam menentukan apakah kondisi lingkungan di lokasi pengukuran telah memenuhi standar baku mutu yang ditetapkan pemerintah. Terdapat 5 parameter pengukuran lingkungan yaitu parameter fisika, kimia dan biologi, ergonomi dan psikologi pekerja. Hal ini sejalan dengan Permenaker no 5 tahun 2018 tentang Keselamatan dan Kesehatan Kerja (K3). Parameter fisika pada lingkungan mencakup iklim kerja, kebisingan, getaran, gelombang radio atau gelombang mikro, sinar ultra ungu (ultra violet), medan magnet statis, tekanan udara dan pencahayaan.

$$
\text { Kampus adalah tempat }
$$

berjalannya kegiatan (pelayanan publik) akademik yang dalam kesehariannya memberikan pelayanan akademik khususnya kepada mahasiswa. Selain itu juga, kampus memiliki peran strategis dalam pengembangan ilmu pengetahuan dan teknologi guna mendukung kemajuan bangsa dan negara. Oleh karenanya, kampus memiliki kewajiban mensukseskan upaya pemerintah dalam hal pengelolaan lingkungan. Peran serta kampus dalam mewujudkan hal tersebut yaitu dengan menyusun dan melaporkan dokumen lingkungan secara berkala sesuai dengan arahan pemerintah. Pentingnya peran serta kampus dalam mendukung program pemerintah diatas, menjadi dasar pelaksanaan penelitian ini. Penelitian ini bertujuan untuk mengukur parameter fisika di lingkungan kampus yang merupakan salah satu dasar dari penyusunan laporan dokumen lingkungan. Hasil penelitian ini dapat dijadikan bahan penyusunan laporan dokumen lingkungan hidup di lingkungan kampus Universitas PGRI Palembang dan menjadi referensi masyarakat dalam pengukuran parameter fisika lingkungan. Hasil penelitian ini juga diharapkan mampu memberikan gambaran kondisi lingkungan di kampus Universitas PGRI Palembang sehingga dapat dijadikan dasar dalam penyusunan program lingkungan kampus agar tercipta lingkungan yang sehat dan nyaman. Kondisi lingkungan yang sehat dan nyaman akan memberikan efek pada motivasi kerja pegawai/pengelola sehingga pelayanan kampus akan lebih optimal. Sebagaimana yang sebutkan oleh Rahmawanti tahun 2014 bahwa terciptanya lingkungan kerja yang nyaman, aman dan menyenangkan merupakan salah satu cara perusahaan untuk dapat meningkatkan kinerja para karyawan.

Berdasarkan uraian diatas, maka rumusan masalah pada penelitian ini adalah bagaimana hasil pengukuran parameter fisika lingkungan di kampus A Universitas PGRI Palembang. Parameter fisika yang diukur dalam penelitian ini dibatasi pada pengukuran kebisingan. Adapun tujuan dari penelitian ini adalah untuk mengetahui nilai tingkat kebisingan di lingkungan kampus A Universitas PGRI Palembang dan membandingkannya dengan nilai ambang batas sesuai baku mutu yang ditetapkan pemerintah.

\section{BAHAN DAN METODE}

Penelitian dilakukan pada Oktober 2020 dengan lokasi pengukuran di lapangan parkir Gedung A, lapangan parkir gedung $\mathrm{B}$ dan lapangan parkir Gedung C. Penelitian yang dilakukan 
adalah penelitian kuantitatif dengan penyajian data menggunakan analisis deskriptif yang akan ditampilkan dalam bentuk tabel hasil pengukuran. Metode yang digunakan dalam penelitian adalah dengan penelitian lapangan, yaitu pengukuran langsung di lapangan (titik pengukuran) untuk mendapatkan data yang akurat. Pengambilan data dilakukan dengan Direct Reading artinya data yang tertera di alat dinyatakan sebagai hasil pengukuran sebenarnya. Pengukuran dilakukan selama 5 hari kerja. dengan waktu pengukuran yaitu pada pagi (07.30 - 08.30 WIB), siang (12.00 - 13.00 WIB) dan sore hari $(15.30-16.30 \mathrm{WIB})$.

Alat dan bahan yang digunakan dalam penelitian ini adalah :

\section{Sound level meter}

2. Lux meter

3. Anemometer Digital

4. Stopwatch

5. Tripod

Pengukuran parameter fisika berupa tingkat kebisingan dilakukan dengan jarak 1 meter dari pinggir lapangan parkir dengan pengambilan data tiap 5 detik selama 10 menit sesuai dengan KepMen LH. No 48 tahun 1996.

Data kebisingan dianalisis dengan menghitung nilai kebisingan eqivalen $\left(\mathrm{L}_{\mathrm{eq}}\right)$ dengan persamaan berikut :

Leq $=\quad 10 \quad \log$
$\left(10^{\mathrm{L} 1 / 10}+10^{\mathrm{L} 2 / 10}+10^{\mathrm{L} 3 / 10}+\ldots ..\right)$
Data hasil analisis untuk tiap variabel pengukuran akan dibandingkan dengan Nilai Ambang Batas (NAB) sebagai baku mutu yang ditetapkan pemerintah melalui peraturan kementerian untuk selanjutnya ditarik simpulan memenuhi standar baku mutu atau tidak.

\section{HASIL DAN PEMBAHASAN}

Penentuan lokasi pengukuran tingkat kebisingan dilakukan dengan mengamati lokasi yang banyak dilalui kendaraan pada jam sibuk kendaraan. Kampus A Universitas PGRI Palembang memiliki 5 lapangan parkir yaitu lapangan parkir gedung $\mathrm{A}$, gedung $\mathrm{B}$, gedung $\mathrm{C}$ dan gedung $\mathrm{H}$ atau lapangan parkir Laboratorium Terpadu dan Perpustakaan. Lapangan parkir gedung A, B, C dan D letaknya berurutan artinya untuk menuju lapangan parkir gedung $\mathrm{B}$ harus melewati lapangan parkir gedung A, demikian pula untuk menuju lapangan parkir gedung $\mathrm{C}$ harus melewati lapangan parkir gedung $\mathrm{B}$ dan seterusnya hingga diakhir terdapat lapangan parkir gedung D. Untuk lapangan parkir gedung $\mathrm{H}$ (Lab terpadu dan Perpustakaan) tidak dilalui kendaraan karena saat penelitian berlangsung lokasi ini sedang ditutup dan tidak difungsikan untuk sementara waktu. Dari pengamatan dilapangan dapat disimpulkan bahwa lokasi yang dilalui banyak kendaraan adalah di lapangan parkir gedung $\mathrm{A}$, lapangan parkir gedung $\mathrm{B}$ dan lapangan parkir gedung $\mathrm{C}$ dan selanjutnya ditetapkan sebagai lokasi titik pengukuran dengan waktu pengukuran didasarkan pada jam sibuk kantor yaitu pada pagi, siang dan sore hari.

Bunyi menyebabkan benda bergetar dan apabila benda bergetar maka akan menyebabkan perubahan tekanan udara disekitar sehingga akan menggerakkan meter penunjuk pada sound level meter. Nilai yang ditunjukkan meter penunjuk inilah yang disebut dengan tingkat kebisingan terukur. Pada penelitian ini, data tingkat kebisingan diambil selama 5 hari kerja dengan waktu pengukuran pada pagi, siang dan sore hari menyesuaikan jam sibuk kendaraan pada lingkungan kampus. 
Tabel 4. Nilai Leq Kebisingan untuk masing-masing titik dan waktu pengukuran

\begin{tabular}{|c|c|c|c|}
\hline Hari/Tanggal & Lokasi & Waktu & $\operatorname{Leq}(\mathrm{dBA})$ \\
\hline \multirow{3}{*}{ Senin, 5 Oktober 2020} & Parkir Gedung A & $\begin{array}{l}\text { Pagi } \\
\text { Siang } \\
\text { Sore }\end{array}$ & $\begin{array}{l}68,7067 \\
69,6857 \\
61,9262\end{array}$ \\
\hline & Parkir Gedung B & $\begin{array}{l}\text { Pagi } \\
\text { Siang } \\
\text { Sore }\end{array}$ & $\begin{array}{l}65,44 \\
62,2549 \\
63,9066\end{array}$ \\
\hline & Parkir Gedung C & $\begin{array}{l}\text { Pagi } \\
\text { Siang } \\
\text { Sore }\end{array}$ & $\begin{array}{l}66,0774 \\
59,9394 \\
66,2809\end{array}$ \\
\hline \multirow{3}{*}{ Selasa, 6 Oktober 2020} & Parkir Gedung A & $\begin{array}{l}\text { Pagi } \\
\text { Siang } \\
\text { Sore }\end{array}$ & $\begin{array}{l}65,9877 \\
65,0642 \\
69,3243\end{array}$ \\
\hline & Parkir Gedung B & $\begin{array}{l}\text { Pagi } \\
\text { Siang } \\
\text { Sore }\end{array}$ & $\begin{array}{l}64,9531 \\
61,4530 \\
67,6474\end{array}$ \\
\hline & Parkir Gedung C & $\begin{array}{l}\text { Pagi } \\
\text { Siang } \\
\text { Sore } \\
\end{array}$ & $\begin{array}{l}73,9548 \\
63,6199 \\
62,2218 \\
\end{array}$ \\
\hline \multirow{3}{*}{ Rabu, 7 Oktober 2020} & Parkir Gedung A & $\begin{array}{l}\text { Pagi } \\
\text { Siang } \\
\text { Sore }\end{array}$ & $\begin{array}{l}66,1049 \\
69,5629 \\
64,3405\end{array}$ \\
\hline & Parkir Gedung B & $\begin{array}{l}\text { Pagi } \\
\text { Siang } \\
\text { Sore }\end{array}$ & $\begin{array}{l}61,7018 \\
59,8817 \\
58,5879\end{array}$ \\
\hline & Parkir Gedung C & $\begin{array}{l}\text { Pagi } \\
\text { Siang } \\
\text { Sore }\end{array}$ & $\begin{array}{l}57,3012 \\
58,2394 \\
58,4920\end{array}$ \\
\hline \multirow{3}{*}{$\begin{array}{c}\text { Jum'at, } 9 \text { Oktober } \\
2020\end{array}$} & Parkir Gedung A & $\begin{array}{l}\text { Pagi } \\
\text { Siang }\end{array}$ & $\begin{array}{l}68,2428 \\
66,4694\end{array}$ \\
\hline & Parkir Gedung B & $\begin{array}{l}\text { Pagi } \\
\text { Siang }\end{array}$ & $\begin{array}{l}66,4694 \\
63,0615 \\
\end{array}$ \\
\hline & Parkir Gedung C & $\begin{array}{l}\text { Pagi } \\
\text { Siang }\end{array}$ & $\begin{array}{l}62,6476 \\
60,0582\end{array}$ \\
\hline \multirow{3}{*}{$\begin{array}{c}\text { Sabtu, } 10 \text { Oktober } \\
2020\end{array}$} & Parkir Gedung A & $\begin{array}{l}\text { Pagi } \\
\text { Siang }\end{array}$ & $\begin{array}{l}69,2768 \\
65,1009\end{array}$ \\
\hline & Parkir Gedung B & $\begin{array}{l}\text { Pagi } \\
\text { Siang }\end{array}$ & $\begin{array}{l}61,531 \\
60,6545\end{array}$ \\
\hline & Parkir Gedung C & $\begin{array}{l}\text { Pagi } \\
\text { Siang }\end{array}$ & $\begin{array}{l}63,8481 \\
61,3909\end{array}$ \\
\hline
\end{tabular}


Jam sibuk kendaraan adalah waktu dimana kendaraan sedang banyak berlalu lalang dibandingkan jam biasa, yaitu pagi hari saat jam masuk kerja antara pukul
07.30 - 08.30 WIB, siang hari antara pukul $12.00-13.00$ WIB (jam istirahat) dan sore hari pukul $15.30-16.30$ WIB (jam pulang).

Tabel 5. Rentang Nilai Leq masing-masing titik pengukuran

\begin{tabular}{|l|l|l|}
\hline Lokasi Titik Pengukuran & Waktu Pengukuran & Rentang Nilai Leq (dBA) \\
\hline Lapangan Parkir Gedung A & Pagi & $65,9877-69,2768$ \\
& Siang & $65,1009-69,6857$ \\
& Sore & $61,9262-69,3243$ \\
\hline Lapangan Parkir Gedung B & Pagi & $61,5310-66,4694$ \\
& Siang & $59,8817-63,0615$ \\
& Sore & $58,5879-67,6474$ \\
\hline Lapangan Parkir Gedung C & Pagi & $57,3012-73,9548$ \\
& Siang & $58,2394-63,6199$ \\
& Sore & $58,4920-66,2809$ \\
\hline
\end{tabular}

Tabel 5 menunjukkan rentang nilai Leq untuk masing-masing titik pengukuran. Secara keseluruhan faktor yang mempengaruhi kebisingan di lingkungan kampus A Universitas PGRI Palembang yaitu suara kendaraan yang lalu lalang pada jam sibuk khususnya suara klakson kendaraan. Jika dilihat dari tabel 5, rentang nilai Leq tertinggi terjadi pada pagi hari yaitu pada jam masuk kantor karena pada jam ini kendaraan pegawai datang hampir bersamaan. Factor lain yang mempengaruhi hasil pengukuran tingkat kebisingan antara lain kelembaban dan tekanan udara. Menurut Bachtiar, dkk (2013) kondisi meteorologi dapat berpengaruh terhadap intensitas suara yang terukur. Factor meteorologi yang dimaksud yaitu suhu, kelembaban, tekanan udara, arah dan kecepatan angin. Berdasarkan Keputusan Menteri Negara Lingkungan Hidup Nomor 48 tahun 1996 tentang baku mutu tingkat kebisingan peruntukan kawasan atau lingkungan kegiatan sekolah dan sejenisnya (lembaga pendidikan) baku mutu yang diperbolehkan adalah 55 dBA. Jika dilihat secara keseluruhan tingkat kebisingan di kampus A Universitas PGRI Palembang yang paling kecil adalah 57,3012 yaitu pada pengukuran Rabu, 7 Oktober 2020 pagi di gedung C. Dan tingkat kebisingan tertinggi 73,9548 pada pengukuran pagi di lapangan parkir gedung C. Berdasarkan tabel diketahui bahwa rentang nilai Leq disetiap titik pengukuran berada diatas ambang batas tingkat kebisingan yang diperbolehkan. Dengan demikian lingkungan kampus A universitas PGRI Palembang belum memenuhi standar baku mutu yang ditetapkan pemerintah yaitu dengan rentang tingkat kebisingan Leq antara 57,3012 - 73,9548 dBA.

\section{KESIMPULAN}

Tingkat kebisingan terukur di lingkungan kampus A Universitas PGRI Palembang yaitu 57,3012 - 73,9548 dBA, nilai ini belum memenuhi standar baku 
mutu pemerintah untuk lembaga pendidikan yaitu 55 dBA.

\section{Ucapan Terima Kasih}

Terima kasih disampaikan kepada Rektor beserta jajarannya dan seluruh tim dari LPPKM Universitas PGRI Palembang yang telah memfasilitasi dengan pendanaan internal universitas dalam pelaksanaan penelitian ini.

\section{DAFTAR PUSTAKA}

Bachtiar, V.S., Dewilda, Y., Wemas, B. V., 2013. Analisis Tingkat Kebisingan dan Usaha Pengendalian pada Unit Produksi pada Suatu Industri di Kota Batam. Jurnal Teknik Lingkungan UNAND, 10 (2) : 85-93

Bambang Yulianto, Darjati. 2017. Fisika Lingkungan. Pusat Pendiidkan Sumber Daya Manusia Kesehatan Badan Pengembangan dan Pemberdayaan Sumber Daya Manusia Kesehatan Kementerian Kesehatan Republik Indonesia.

Bleszeinsky, G. (2019). Partisipasi Masyarakat dalam Pelestarian Lingkungan di kawasan Pantai Padang. JESS (Journal of Education on Social Science), 3(1), 1-13.

Dewanty, R. A., \& Sudarmaji, S. (2016). Impact Analysis of Noise Intensity with Hearing Loss on Laundry Worker. JURNAL KESEHATAN LINGKUNGAN, 8(2), 229-237

Edi, D., \& Betshani, S., (2009). Analisis Data dengan Menggunakan ERD dan Model Konseptual Data Warehouse. Jurnal informatika Vol 5 No 1, 71-85.

Hamuna, B., dkk. (2018). Kajian Kualitas Air Laut dan Indeks Pencemaran Berdasarkan Parameter FisikaKimia di Perairan Distrik
Depapre, Jayapura. Jurnal Ilmu Lingkungan, 16(1), 35-43.

Indrawan, D., \& Oginawati, K, (2014). Analisis Paparan BTX Terhadap Pekerja di PT. Pertamina RU IV Cilacap. Jurnal Teknik Lingkungan, 20(2), 132-141.

Majid, A. A., Prasetyo, D., \& Danarto, Y. C. (2012). Pembuatan biodiesel dari minyak jelantah dengan menggunakan iradiasi gelombang mikro.

Peraturan Menteri Kesehatan Republik Indonesia No 48 tahun 2016 tentang Standar Keselamatan dan Kesehatan Kerja Perkantoran.

Peraturan Menteri Ketenagakerjaan Republik Indonesia Nomor 5 Tahun 2018 tentang Keselamatan dan Kesehatan Kerja Lingkungan Kerja.

Peraturan Menteri Lingkungan Hidup dan Kehutanan Republik Indonesia nomor 102 tahun 2016 tentang Pedoman Penyusunan Dokumen Lingkungan Hidup Bagi Usaha dan/atau Kegiatan yang telah Memiliki Izin Usaha dan/atau Kegiatan tetapi Belum Memiliki Dokumen Lingkungan Hidup.

Peraturan Menteri Tenaga Kerja Dan Transmigrasi Nomor 13 Tahun 2011 tentang Nilai Ambang Batas Faktor Fisika dan Faktor Kimia di Tempat Kerja.

Rahmawanti, Nela Pima. 2014. Pengaruh Lingkungan Kerja Terhadap Kinerja Karyawan (studi pada karyawan Kantor Pelayanan Pajak Pratama Malang Utara). Jurnal Administrasi Bisnis Vol. 8 No. 2 Maret 2014. Universitas Brawijaya. Malang.

Sugiyono. 2010. Metode Penelitian Pendidikan Pendekatan Kuantitatif, kualitatif, dan R\&D. Bandung: Alfabeta.

Tyagi, V., Kumar, K., \& Jain, V. K. 2013. Road Traffic Noise 
Analisis Tingkat Kebisingan,...Atina, Jumingin, Widya R. dan Indah S.,...Sainmatika,...Volume 17,...No.2,...Desember $2020, \ldots 126-132$

Attenuation by Vegetation Belts at Some Sites in the Tarai Region of India. New Delhi, India. Journal Archives of Accoustis. 38 (3) : 389-395.

Vidyautami, D. N., Huboyo, H. S., \& Hadiwidodo, M. (2015). Pengaruh Penggunaan Ventilasi (AC Dan Non AC) dalam Ruangan Terhadap Keberadaan Mikroorganisme Udara (Studi Kasus: Ruang Kuliah Jurusan Teknik Sipil Universitas Diponegoro) (Doctoral dissertation, Diponegoro University). 